\title{
Common Modifiable and Non-Modifiable Risk Factors of Cardiovascular Disease (CVD) among Pacific Countries
}

\author{
Masoud Mohammadnezhad1*, Tamara Mangum², William May³, Joshua Jeffrey Lucas ${ }^{4}$, Stanley Ailson ${ }^{5}$ \\ ${ }^{1}$ Discipline of Health Promotion, Department of Public Health \& Primary Health Care, Fiji National University, Suva, Fiji \\ ${ }^{2}$ Discipline of Emergency Health Management, Department of Public Health \& Primary Health Care, Fiji National University, \\ Suva, Fiji \\ ${ }^{3}$ College of Medicine, Nursing and Health Sciences, Department of Health Sciences, Fiji National University, Suva, Fiji \\ ${ }^{4}$ Department of Public Health, Ministry of Health, Weno, Federated States of Micronesia \\ ${ }^{5}$ Department of Public Health, Ministry of Health, Port Vila, Vanuatu \\ Email: ^masoud.m@fnu.ac.fj
}

How to cite this paper: Mohammadnezhad, M., Mangum, T., May, W., Lucas, J.J. and Ailson, S. (2016) Common Modifiable and Non-Modifiable Risk Factors of Cardiovascular Disease (CVD) among Pacific Countries. World Journal of Cardiovasculat Surgery, 6, 153-170. http://dx.doi.org/10.4236/wjcs.2016.611022

Received: October 31, 2016

Accepted: November 27, 2016

Published: November 30, 2016

Copyright $\odot 2016$ by authors and Scientific Research Publishing Inc. This work is licensed under the Creative Commons Attribution International License (CC BY 4.0).

http://creativecommons.org/licenses/by/4.0/ (c) (i) Open Access

\section{Abstract}

Introduction: Modifiable and non-modifiable risk factors contribute to the significant rise of non-communicable diseases (NCDs), most notably cardiovascular disease (CVD), in the Pacific Island nations. The aim of this study is to review previously published articles to understand common modifiable and non-modifiable risk factors of CVD among Pacific countries. Methods: This systematic review is conducted using different databases including; Scopus, Medline, EMBASE, and psycINFO. This systematic review is based on the Cochrane review process. All articles published in the English language from $1^{\text {st }}$ January 2000 to $1^{\text {st }}$ September 2016, will be included in the study. After reviewing all of the articles' titles, abstracts, and full text, the final articles were reviewed and the relevant data was included in the data extraction sheet. A descriptive analysis was conducted to measure the common risk factors of CVD in Pacific countries. Results: Overall, 45 articles met the inclusion criteria of the study. The results showed that age was the most common non-modifiable risk factor while diabetes, high blood lipid, and high blood pressure were the most common modifiable risk factors of CVD. There were only three interventional studies which had all of the significant influences in reducing the risk factors of CVD when the results were compared with the control group. Conclusion: While it is not possible to change the non-modifiable risk factors for CVD, we encourage policy makers to use the results of this study to develop health promotion strategies to address the modifiable risk factors for CVD. Interventional strategies are highly recommended in the Pacific countries to tackle the modifiable risk factors for CVD. 


\section{Keywords}

Cardiovascular Disease, Modifiable Risk Factors, Non-Modifiable Risk Factors, Pacific

\section{Introduction}

Cardiovascular disease (CVD) is a lifestyle disease that is defined as heart and blood vessel disease, also known as heart disease, which is related to atherosclerosis [1).

Globally, according to the World Health Organization (WHO), an estimated 16.7 million people die from CVD annually. Of the total deaths, about 8.6 million are women and 4.5 million are men [2]. In Canada, an estimated 8 million deaths are caused by CVD [3]. In the United Kingdom, an estimated 245,000 deaths occur as a result of CVD [4]. The burden of CVD is not only affecting developed countries, instead the burden is worldwide. According to WHO (2009), 16.6 million deaths attributed to CVD worldwide. $80 \%$ of deaths are in the developing countries, including Pacific regions [5]. The prevalence of CVD in the Pacific was $21.1 \%$ in 2011 with an increasing trend [6]. For instance, $26.2 \%$ of Samoan diabetic adults had CVD [7].

Some of the identified risk factors of CVD in the world are; high blood pressure, rapid acculturation and improvement in economic conditions, economical transition, increased tobacco use, high blood lipids, physical inactivity, over-weight and obese, diabetes and poor nutrition [8] [9]. In the Asia-Pacific regions there was also some research done to identify some of the major risk factors for CVD. For instance, Asian Pacific Countries Society (APCS) identified obesity, diabetes, dyslipidemia and hypertension as risk factors for CVD in the Asia-Pacific regions [10]. Furthermore, according to [11], the study identified five other risk factors which are chiefly; socio-demographic, economical transition, elevated blood pressure, cigarette smoking, lipids and excess body weight. It has also been found that different ethnic groups have their own risk behaviors for CVD [12] [13].

Based on the literature review, there was no systematic review study in the Pacific identifying the risk factors or determinants of CVD. Therefore, the main purpose of this systematic review is to identify the determinants of CVD existing in the Pacific region as a platform for the Pacific Island Countries (PIC) to develop their own health promotion and prevention strategies on how to tackle the identified risks in the future. On the other hand, as we know CVD has a greater impact to the developing nation hence, to reduce the burden from happening we have to identify the risk as possible in-order to find solution on how to promote and prevent people life.

\section{Methodology}

This was a systematic review which was conducted using different databases including Scopus, Medline, EMBASE, psycINFO. The present review was based on the Cochrane review process. These databases were used based on their availability and also their 
frequency of use in similar previous systematic review studies. All articles published in the English language between 1 January 2000 and 1September 2016, using quantitative and qualitative research, were included in the search. Review articles, news articles and conference abstracts were excluded. Key words used to search in selected databases included "Pacific" AND "Cardiovascular" OR "cardiac" OR "heart disease" AND "risk factors". The systematic review of the studies was conducted in three stages. In the first stage, the titles of all searched studies were screened and those not relevant were omitted. In the second stage, the abstract of the remaining articles were reviewed and those not relevant or if they didn't have a clear methodology were omitted. In the third stage, the full text of the remaining articles was reviewed and some of them omitted (Figure 1).

Finally, 31 articles were included in the review. The bibliography of those articles were reviewed and 14 articles were added so 45 studies were considered for the final study. All relevant information was extracted and included in the data extraction sheet. The data extraction sheet was in four parts including the study, participants, methodology, and results (Appendix 1 and Appendix 2). A descriptive analysis was conducted using frequency and percentage to measure the common risk factors of CVD in Pacific countries.

\section{Results}

The pooled number of people in 45 studies was 10,376,734. The result of the study shows that eight studies focused on older people aged 50 years old and over. Three studies focused on children and adolescents aged less than 20 years old. The rest of the thirty studies (66.7\%) were conducted among adults aged 20 to 49 years old. Ages of the participants in four of the studies were not reported.

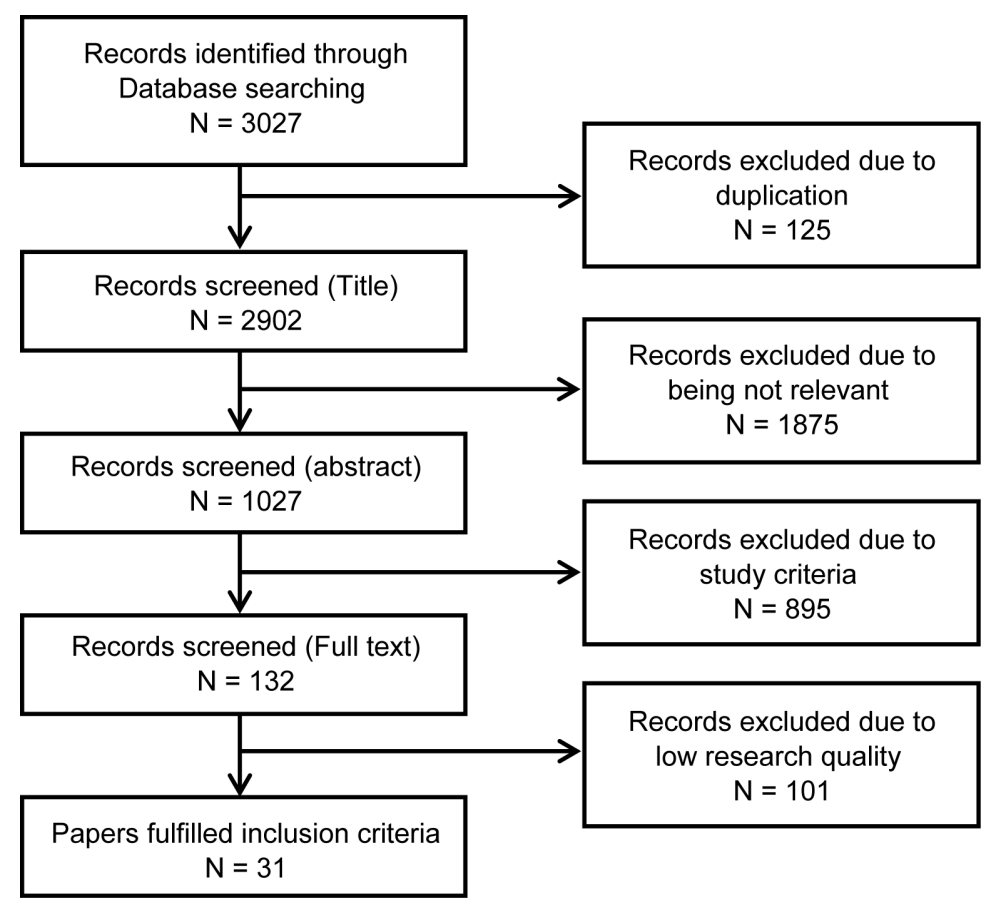

Figure 1. Article selection process. 
The results show that $38 \%$ of the studies were published from 2000 to $2005,24 \%$ of the studies were published in the years 2006 to 2010, while the remaining $38 \%$ of the studies were published in 2011 to 2016. The majority of the studies (73\%) were cohort studies while $2 \%$ of the studies were case control. The majority of the participants in the studies were from the Asia Pacific region (73\%), while in 7\% of the studies, participants were from United States of America. Thirty-three percent of the studies focused on both males and females, while $4.5 \%$ of the studies focused on male participants only (Table 1).

Figure 2 shows the frequency of the studies based on non-modifiable risk factors of cardiovascular disease. Age was the most frequent risk factor (11 studies) while ethnicity was the risk factor least associated with cardiovascular disease in the Pacific countries.

Figure 3 shows that diabetes and abnormal blood lipids, among the modifiable risk factors for cardiovascular disease, are more common in Pacific islanders, based on the studies. This was followed by high blood pressure, overweight and obesity and smoking, while alcohol intake, among the modifiable risk factors, is the least common.

Table 1. Characteristics of the studies $(n=45)$.

\begin{tabular}{ccc}
\hline Factor & Frequency & Percentage \\
\hline Year of the study & 17 & 38 \\
$2000-2005$ & 11 & 24 \\
$2006-2010$ & 17 & 38 \\
$2011-2016$ & & \\
Type of study & 32 & 73 \\
Cohort & 8 & 18 \\
Cross-sectional & 3 & 7 \\
RCTs & 1 & 2 \\
Case-control & & 82 \\
Countries of the study & 37 & 11 \\
Asia Pacific & 5 & 7 \\
Pacific region & 3 & 33.3 \\
United states & 19 & 4.5 \\
Gender of participants & & 20 \\
Male and female & 2 & 42.2 \\
Male & 9 & \\
Female & 15 & \\
Unknown & & \\
\hline
\end{tabular}




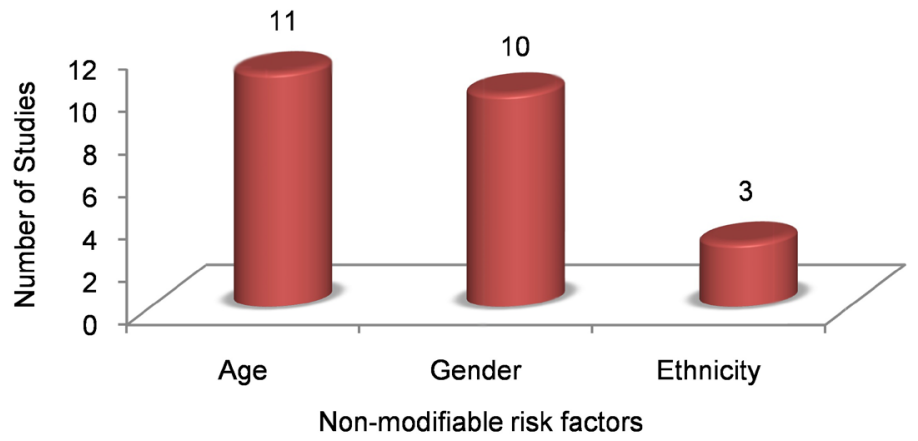

Figure 2. Frequency of studies based on Non-modifiable risk factors.

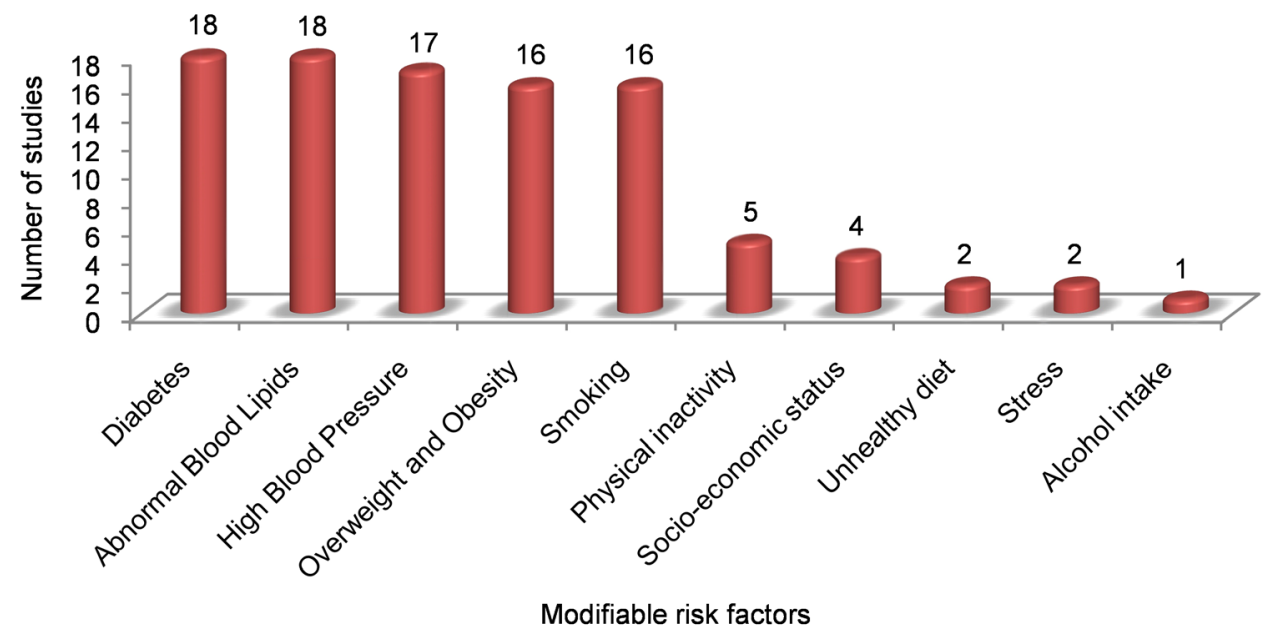

Figure 3. Frequency of studies based on modifiable risk factors.

Effectiveness of the intervention:

As the results revealed, there were three randomized controlled trials (RCTs) implemented to reduce the risk factors of cardiovascular disease. Mark et.al. (2011) used "small-sided games and based exercise on fitness and health parameters among Pacific adults over four weeks". The effectiveness of the intervention was greater among intervention participants than the control participants; cardiorespiratory fitness $(p=0.003)$, leg strength $(\mathrm{p}=0.04)$ and high density lipoprotein $(\mathrm{p}=0.02)$. The EunJoo Cho et al. (2013) study showed that proactive multifactorial intervention was more effective in reducing cardiovascular disease risk among the intervention group than usual care among participants from both Pacific Asia $(-37.1 \%$ versus $-3.5 \%, \mathrm{p}<0.001)$ and non-Pacific Asia countries $(-31.1 \%$ versus $-4.2 \%, \mathrm{p}<0.001)$. In addition, the EunJoo Cho et al. (2014) study also showed that there was a greater reduction in systolic blood pressure (-19.1 vs. $-9.0,95 \%$ CI-8.33 - 0.52), DBP (-8.3 vs. $-3.9,95 \%$ CI-3.83, -3.9 ), low density lipoprotein cholesterol ( -20.5 vs. $1.2,95 \%$ CI-24.66, -16.97 , and total cholesterol (-28.2 vs. 3.7, 95\% CI-38.25, -24.35) in the proactive multifactorial intervention (PMI) arm compared with the usual care (UC) arm at week 52 for Pacific Asia patients. 


\section{Discussion}

The present study highlighted the most frequent non-modifiable and modifiable risk factors of CVD in the Pacific region.

The results showed that age was the main non-modifiable risk factor of CVD among Pacific Asian countries. Most of the studies conducted among adults and older people showed that increasing age increases the chances of getting CVD [10]. CVD affects all age groups in the Pacific as a result of modernization associated with the modifiable risk factors for CVD, including diabetes, abnormal blood lipids, high blood pressure, overweight and obesity, unhealthy diets, physical inactivity, socio-economic status, and alcohol intake [14] [15]. Nowadays, in the Pacific region, all age groups, even adolescents, are more likely to develop the risk factors for CVD at an early age as a result of modernization and changes in the family structure [16]. In the past, Pacific people used to live in extended families where they shared meals together, they worked together, and their children played together outdoors. As a result of modernization, there is a change in family structure in the Pacific islands where people started to shift into nuclear families, rather than extended [17].

Pacific islanders now grow up in a modern world where they are being exposed to unhealthy foods through media or advertisement, which result in being the first food choices [18]. Physical inactivity and unhealthy diets are risk factors for CVD and this shows that Pacific islanders are more likely to have CVD if they don't adopt a healthy lifestyle [19]. In the Pacific islands, culture plays an important role on the three different ethnic groups, namely Melanesians, Polynesians, and Micronesians, way of living. Pacific island men and women suffer from CVD as a result of the modifiable risk factors such as physical inactivity, high cholesterol, high blood pressure, and smoking, to name a few of them for both genders.

According to the ACPS; "17,050 deaths accounted for Asians and Pacific Islanders due to CVD in $2011,31.5 \%$ in men and $32.4 \%$ in female [20]". Numerous lifestylerelated factors can cause the difference in the death rates in CVD among men and women in the Pacific. For example, in a Polynesian island country such as Tonga, women's responsibilities involve house chores, taking care of the children, and many others which stood as barriers for women to engage in physical activity [21]. In Melanesian island countries like Vanuatu and Fiji, dress code is one of the barriers that prevent women from engaging in any sort of physical activity. Similar to Tonga and Vanuatu, Micronesian women have the same barriers that prevent them from engaging in any sort of physical activity [22]. Ethnicity is another non-modifiable risk factor for CVD. According to the British heart foundation, these different ethnic groups have their own culture and traditions that they are engaged in [23].

As a result of these cultural and traditional differences, there are some things that restrict them from doing physical activity, which is a risk factor for CVD. In the Pacific, women who have limited transport options may be unable to travel to physical activity facilities because of the cultural barriers [24]. Another example is that some cultural expectations may restrict the involvement of women in certain forms of physical activ- 
ity, which increases their likelihood of becoming obese, another risk factor for developing non-communicable diseases, including CVD [25] [26]. Nowadays, different ethnic groups are adopting similar behaviours, especially the engagement in the risk behaviours of CVD, like inactive physical activities, smoking, hypertension and obesity. This was shown by a study done in the Asia Pacific based on two different ethnic groups, namely Asian and Non-Asian peoples [27]. The results of the study shows that most traditional cardiovascular risk factors, including high blood pressure, obesity, and cigarette smoking, is highly associated to heart diseases in both ethnic groups, despite the differences in ethnicity status [28].

According to the results of this study, there were ten identified modifiable risk factors for CVD in the Pacific and diabetes is ranked the highest, followed by abnormal blood lipid, high blood pressure, overweight, smoking and the list continues until the least on the graph, which is alcohol intake [29]. Nevertheless, despite the hierarchy of the identified risk factors, they are all inter-related. For instance, those exposed to an unhealthy diet like high sugary and salty foods, will eventually developed diabetes or hypertension, which is a risk for CVD [30]. On the other hand, those with low socioeconomic status cannot afford to buy healthy food so they buy the cheap, unhealthy diet foods that will increase their chances of becoming overweight, resulting in high lipid deposition in the adipose tissue, which will eventually increase the chances of developing hypertension and diabetes that can later lead to CVD [31].

In conclusion, CVD is caused by both modifiable and non-modifiable predisposing risk factors and can be prevented mainly through health promoting life-style interventions. People need to know how to manage and monitor these risk factors. It is necessary to increase awareness among health care providers and systems serving Pacific islanders, at childhood stage, in suggesting accurate information, early screening and treatment, and recommend appropriate behavioural modifications for decreasing the prevalence of cardiovascular disease.

The Cochrane review process was used to develop the search strategy, appraise the articles, and analyze the data. However, in this study two reviewers independently extracted data from different types of studies and all discrepancies were agreed to by discussion with a third reviewer. This study had some limitations associated with the quality of the reviewed articles and also the approach. However, the quality of studies assessed did not show an assessment of bias that may have characterized the identified studies. Majority of studies included in this review were descriptive so there are potential biases that may affect the results of this study, such as: self-selected samples, poor description of participants, and non-validated data collection instruments.

\section{References}

[1] Santulli, G. (2013) Epidemiology of Cardiovascular Disease in the 21st Century: Updated Numbers and Updated Facts. Journal of Cardiovascular Disease, 1, 1-2.

[2] Lloyd-Jones, D., Adams, R.J., Brown, T.M., Carnethon, M., Dai, S., De Simone, G., et al. (2010) Heart Disease and Stroke Statistics-2010 Update a Report from the American Heart Association. Circulation, 121, e46-e215. 
https://doi.org/10.1161/CIRCULATIONAHA.109.192667

[3] Allender, S., Peto, V., Scarborough, P., Boxer, A. and Rayner, M. (2007) Coronary Heart Disease Statistics.

[4] Lloyd-Jones, D., Adams, R., Carnethon, M., De Simone, G., Ferguson, T.B., Flegal, K., et al. (2009) Heart Disease and Stroke Statistics-2009 Update a Report from the American Heart Association Statistics Committee and Stroke Statistics Subcommittee. Circulation, 119, e21-e181. https://doi.org/10.1161/CIRCULATIONAHA.108.191261

[5] WHO (2009) World Health Statistics 2009: World Health Organization. Geneva.

[6] Celermajer, D.S., Chow, C.K., Marijon, E., Anstey, N.M. and Woo, K.S. (2012) Cardiovascular Disease in the Developing World: Prevalences, Patterns, and the Potential of Early Disease Detection. Journal of the American College of Cardiology, 60, 1207-1216. https://doi.org/10.1016/j.jacc.2012.03.074

[7] Sundborn, G.B.M. (2009) Cardiovascular Disease Risk Factors and Diabetes in Pacific Adults: The Diabetes Heart and Health Study (DHAH), Auckland, New Zealand 2002/03. The University of Auckland, Auckland. https://researchspace.auckland.ac.nz/docs/uoa-docs/rights.htm

[8] Hyun, K.K., Huxley, R.R., Arima, H., Woo, J., Lam, T.H., Ueshima, H., et al. (2013) A Comparative Analysis of Risk Factors and Stroke Risk for Asian and Non-Asian Men: The Asia Pacific Cohort Studies Collaboration. International Journal of Stroke, 8, 606-611. https://doi.org/10.1111/ijs.12166

[9] Lin, W.-Y., Lee, L.-T., Chen, C.-Y., Lo, H., Hsia, H.-H., Liu, I.-L., et al. (2002) Optimal Cut-Off Values for Obesity: Using Simple Anthropometric Indices to Predict Cardiovascular Risk Factors in Taiwan. International Journal of Obesity \& Related Metabolic Disorders, 26, 1232-1238. https://doi.org/10.1038/sj.ijo.0802040

[10] Asia Pacific Cohort Studies Collaboration (2004) Body Mass Index and Cardiovascular Disease in the Asia-Pacific Region: An Overview of 33 Cohorts Involving 310,000 Participants. International Journal of Epidemiology, 33, 751-758. https://doi.org/10.1093/ije/dyh163

[11] Woodward, M., Barzi, F., Feigin, V., Gu, D., Huxley, R., Nakamura, K., et al. (2007) Associations between High-Density Lipoprotein Cholesterol and Both Stroke and Coronary Heart Disease in the Asia Pacific Region. European Heart Journal, 28, 2653-2660. https://doi.org/10.1093/eurheartj/ehm427

[12] Holvoet, P., et al. (2007) The Relationship between Oxidized LDL and Other Cardiovascular Risk Factors and Subclinical CVD in Different Ethnic Groups: The Multi-Ethnic Study of Atherosclerosis (MESA). Atherosclerosis, 194, 245-252. https://doi.org/10.1016/j.atherosclerosis.2006.08.002

[13] Chan, W.C., Wright, C., Riddell, T., Wells, S., Kerr, A.J., Gala, G., et al. (2008) Ethnic and Socioeconomic Disparities in the Prevalence of Cardiovascular Disease in New Zealand. The New Zealand Medical Journal (Online), 121, 11-20.

[14] Asia Pacific Cohort Studies Collaboration (2003) The Effects of Diabetes on the Risks of Major Cardiovascular Diseases and Death in the Asia-Pacific Region. Diabetes Care, 26, 360-366. https://doi.org/10.2337/diacare.26.2.360

[15] Asia Pacific Cohort Studies Collaboration (2004) Serum Triglycerides as a Risk Factor for Cardiovascular Diseases in the Asia-Pacific Region. Circulation, 110, 2678-2686. https://doi.org/10.1161/01.CIR.0000145615.33955.83

[16] Woodward, M., Peters, S.A., Batty, G.D., Ueshima, H., Woo, J., Giles, G.G., et al. (2015) Socioeconomic Status in Relation to Cardiovascular Disease and Cause-Specific Mortality: A 
Comparison of Asian and Australasian Populations in a Pooled Analysis. BMJ Open, 5, e006408. https://doi.org/10.1136/bmjopen-2014-006408

[17] Khor, G.L. (2001) Cardiovascular Epidemiology in the Asia-Pacific Region. Asia Pacific Journal of Clinical Nutrition, 10, 76-80. https://doi.org/10.1046/j.1440-6047.2001.00230.x

[18] Spreadbury, I. and Samis, A.J. (2013) Evolutionary Aspects of Obesity, Insulin Resistance, and Cardiovascular Risk. Current Cardiovascular Risk Reports, 7, 136-146. https://doi.org/10.1007/s12170-013-0293-1

[19] Jørgensen, T., Capewell, S., Prescott, E., Allender, S., Sans, S., Zdrojewski, T., et al. (2013) Population-Level Changes to Promote Cardiovascular Health. European Journal of Preventive Cardiology, 20, 409-421. https://doi.org/10.1177/2047487312441726

[20] Asia Pacific Cohort Studies Collaboration (2007) The Burden of Overweight and Obesity in the Asia-Pacific Region. Obesity Reviews, 8, 191-196. https://doi.org/10.1111/j.1467-789X.2006.00292.x

[21] Juarbe, T., Turok, X.P. and Pérez-Stable, E.J. (2002) Perceived Benefits and Barriers to Physical Activity among Older Latina Women. Western Journal of Nursing Research, 24, 868-886. https://doi.org/10.1177/019394502237699

[22] Huxley, R., Barzi, F. and Woodward, M. (2006) Excess Risk of Fatal Coronary Heart Disease Associated with Diabetes in Men and Women: Meta-Analysis of 37 Prospective Cohort Studies. BMJ, 332, 73-78. https://doi.org/10.1136/bmj.38678.389583.7C

[23] Murphy, C., et al. (2007) Vascular Dysfunction and Reduced Circulating Endothelial Progenitor Cells in Young Healthy UK South Asian Men. Arteriosclerosis, Thrombosis, and Vascular Biology, 27, 936-942. https://doi.org/10.1161/01.ATV.0000258788.11372.d0

[24] Bauman, A.E., Reis, R.S., Sallis, J.F., Wells, J.C., Loos, R.J., Martin, B.W., et al. (2012) Correlates of Physical Activity: Why Are Some People Physically Active and Others Not? The Lancet, 380, 258-271. https://doi.org/10.1016/S0140-6736(12)60735-1

[25] Hoebeke, R. (2008) Low-Income Women's Perceived Barriers to Physical Activity: Focus Group Results. Applied Nursing Research, 21, 60-65.

https://doi.org/10.1016/j.apnr.2006.06.002

[26] Mansfield, E.D. and Pollins, B.M. (2009) Economic Interdependence and International Conflict: New Perspectives on an Enduring Debate. University of Michigan Press, Ann Arbor.

[27] Asia Pacific Cohort Studies Collaboration (2005) A Comparison of the Associations between Risk Factors and Cardiovascular Disease in Asia and Australasia. European Journal of Cardiovascular Prevention \& Rehabilitation, 12, 484-491. https://doi.org/10.1097/01.hjr.0000170264.84820.8e

[28] American Diabetes Association (2004) Blood Glucose and Risk of Cardiovascular Disease in the Asia Pacific Region. Diabetes Care, 27, 2836-2842.

https://doi.org/10.2337/diacare.27.12.2836

[29] Cassels, S. (2006) Overweight in the Pacific: Links between Foreign Dependence, Global Food Trade, and Obesity in the Federated States of Micronesia. Globalization and Health, 2, 10. https://doi.org/10.1186/1744-8603-2-10

[30] Martiniuk, A.L., Lee, C.M., Lawes, C.M., Ueshima, H., Suh, I., Lam, T.H., et al. (2007) Hypertension: Its Prevalence and Population-Attributable Fraction for Mortality from Cardiovascular Disease in the Asia-Pacific Region. Journal of Hypertension, 25, 73-79. https://doi.org/10.1097/HJH.0b013e328010775f

[31] Bassuk, S.S. and Manson, J.E. (2005) Epidemiological Evidence for the Role of Physical Activity in Reducing Risk of Type 2 Diabetes and Cardiovascular Disease. Journal of Applied 
Physiology, 99, 1193-204. https://doi.org/10.1152/japplphysiol.00160.2005

[32] Grey, C., Wells, S., Riddell, T., Kerr, A., Gentles, D., Pylypchuk, R., et al. (2010) A Comparative Analysis of the Cardiovascular Disease Risk Factor Profiles of Pacific Peoples and Europeans Living in New Zealand Assessed in Routine Primary Care: PREDICT CVD-11. The New Zealand Medical Journal, 123, 62-75.

[33] Huxley, R.R., Barzi, F., Woo, J., Giles, G., Lam, T.H., Rahimi, K., et al. (2014) A Comparison of Risk Factors for Mortality from Heart Failure in Asian and Non-Asian Populations: An Overview of Individual Participant Data from 32 prospective Cohorts from the Asia-Pacific Region. BMC Cardiovascular Disorders, 14, 61. https://doi.org/10.1186/1471-2261-14-61

[34] Rana, J.S., Tabada, G.H., Solomon, M.D., Lo, J.C., Jaffe, M.G., Sung, S.H., et al. (2016) Accuracy of the Atherosclerotic Cardiovascular Risk Equation in a Large Contemporary, Multiethnic Population. Journal of the American College of Cardiology, 67, 2118-2130. https://doi.org/10.1016/j.jacc.2016.02.055

[35] Lee, C.M.Y., Barzi, F., Woodward, M., Batty, G.D., Giles, G.G., Wong, J.W., et al. (2009) Adult Height and the Risks of Cardiovascular Disease and Major Causes of Death in the Asia-Pacific Region: 21000 Deaths in 510000 Men and Women. International Journal of Epidemiology, 38, 1060-1071. https://doi.org/10.1093/ije/dyp150

[36] Hosey, G., Samo, M., Gregg, E., Barker, L., Padden, D. and Bibb, S. (2014) Association of Socioeconomic Position and Demographic Characteristics with Cardiovascular Disease Risk Factors and Healthcare Access among Adults Living in Pohnpei, Federated States of Micronesia. International Journal of Chronic Diseases, 2014, Article ID: 595678. https://doi.org/10.1155/2014/595678

[37] Association, A.D. (2004) Blood Glucose and Risk of Cardiovascular Disease in the Asia Pacific Region. Diabetes Care, 27, 2836-2842. https://doi.org/10.2337/diacare.27.12.2836

[38] Asia Pacific Cohort Studies Collaboration (2003) Blood Pressure and Cardiovascular Disease in the Asia Pacific Region. Journal of Hypertension, 21, 707-716. https://doi.org/10.1097/00004872-200304000-00013

[39] Asia Pacific Cohort Studies Collaboration (2003) Blood Pressure Indices and Cardiovascular Disease in the Asia Pacific Region a Pooled Analysis. Hypertension, 42, 69-75. https://doi.org/10.1161/01.HYP.0000075083.04415.4B

[40] Chansavang, Y., Elley, C.R., McCaffrey, B., Davidson, C., Dewes, O. and Dalleck, L. (2015) Feasibility of an After-School Group-Based Exercise and Lifestyle Programme to Improve Cardiorespiratory Fitness and Health in Less-Active Pacific and Maori Adolescents. Journal of Primary Health Care, 7, 57-64.

[41] Schaaf, D., Scragg, R. and Metcalf, P. (2000) Cardiovascular Risk Factors Levels of Pacific People in a New Zealand Multicultural Workforce. New Zealand Medical Journal, 113, 3-5.

[42] Witter, T., Poudevigne, M., Lambrick, D.M., Faulkner, J., Lucero, A.A., Page, R., et al. (2015) A Conceptual Framework for Managing Modifiable Risk Factors for Cardiovascular Diseases in Fiji. Perspectives in Public Health, 135, 75-84. https://doi.org/10.1177/1757913913500045

[43] Asia Pacific Cohort Studies Collaborations (2006) Central Obesity and Risk of Cardiovascular Disease in the Asia Pacific Region. Asia Pacific Journal of Clinical Nutrition, 15, 287292.

[44] Nakamura, K., Barzi, F., Lam, T.-H., Huxley, R., Feigin, V.L., Ueshima, H., et al. (2008) Cigarette Smoking, Systolic Blood Pressure, and Cardiovascular Diseases in the Asia-Pacific Region. Stroke, 39, 1694-1702. https://doi.org/10.1161/STROKEAHA.107.496752 
[45] Asia Pacific Cohort Studies Collaboration (2007) Cholesterol, Diabetes and Major Cardiovascular Diseases in the Asia-Pacific Region. Diabetologia, 50, 2289-2297. https://doi.org/10.1007/s00125-007-0801-2

[46] Asia Pacific Cohort Studies Collaboration (2003) Cholesterol, Coronary Heart Disease, and Stroke in the Asia Pacific Region. International Journal of Epidemiology, 32, 563-572. https://doi.org/10.1093/ije/dyg106

[47] Sundborn, G., Metcalf, P., Gentles, D., Scragg, R., Schaaf, D., Dyall, L., et al. (2008) Ethnic Differences in Cardiovascular Disease Risk Factors and Diabetes Status for Pacific Ethnic Groups and Europeans in the Diabetes Heart and Health Survey (DHAH) 2002-2003, Auckland New Zealand. The New Zealand Medical Journal, 121, 28-39.

[48] Tsukinoki, R., Murakami, Y., Huxley, R., Ohkubo, T., Fang, X., Suh, I., et al. (2012) Does Body Mass Index Impact on the Relationship between Systolic Blood Pressure and Cardiovascular Disease? Meta-Analysis of 419488 Individuals from the Asia Pacific Cohort Studies Collaboration. Stroke, 43, 1478-1483.

https://doi.org/10.1161/STROKEAHA.112.650317

[49] Asia Pacific Cohort Studies Collaboration (2005) Does Sex Matter in the Associations between Classic Risk Factors and Fatal Coronary Heart Disease in Populations from the Asia-Pacific Region? Journal of Women's Health, 14, 820-828.

https://doi.org/10.1089/jwh.2005.14.820

[50] Arima, H., Murakami, Y., Lam, T.H., Kim, H.C., Ueshima, H., Woo, J., et al. (2012) Effects of Prehypertension and Hypertension Subtype on Cardiovascular Disease in the Asia-Pacific Region. Hypertension, 59, 1118-1123. https://doi.org/10.1161/HYPERTENSIONAHA.111.187252

[51] Dobson, J., Steer, A.C., Colquhoun, S. and Kado, J. (2012) Environmental Factors and Rheumatic Heart Disease in Fiji. Pediatric Cardiology, 33, 332-336. https://doi.org/10.1007/s00246-011-0139-X

[52] Gu, Y., Warren, J., Walker, N. and Kennelly, J. (2013) Gender Differences in Cardiovascular Disease Risk Management for Pacific Islanders in Primary Care. Quality in Primary Care, 21, 275-285.

[53] Huxley, R.R., Barzi, F., Lam, T.H., Czernichow, S., Fang, X., Welborn, T., et al. (2011) Isolated Low Levels of High-Density Lipoprotein Cholesterol Are Associated with an Increased Risk of Coronary Heart Disease an Individual Participant Data Meta-Analysis of 23 Studies in the Asia-Pacific Region. Circulation, 124, 2056-2064. https://doi.org/10.1161/CIRCULATIONAHA.111.028373

[54] Asia Pacific Cohort Studies Collaboration (2005) Joint Effects of Systolic Blood Pressure and Serum Cholesterol on Cardiovascular Disease in the Asia Pacific Region. Circulation, 112, 3384-3390. https://doi.org/10.1161/CIRCULATIONAHA.105.537472

[55] Howard, B.V., Criqui, M.H., Curb, J.D., Rodabough, R., Safford, M.M., Santoro, N., et al. (2003) Risk Factor Clustering in the Insulin Resistance Syndrome and Its Relationship to Cardiovascular Disease in Postmenopausal White, Black, Hispanic, and Asian/Pacific Islander Women. Metabolism, 52, 362-371. https://doi.org/10.1053/meta.2003.50057

[56] Roy, S.S., Foraker, R.E., Girton, R.A. and Mansfield, A.J. (2015) Posttraumatic Stress Disorder and Incident Heart Failure among A Community-Based Sample of US Veterans. American Journal of Public Health, 105, 757-763. https://doi.org/10.2105/AJPH.2014.302342

[57] Feigin, V., Parag, V., Lawes, C.M., Rodgers, A., Suh, I., Woodward, M., et al. (2005) Smoking and Elevated Blood Pressure Are the Most Important Risk Factors for Subarachnoid Hemorrhage in the Asia-Pacific Region: An Overview of 26 Cohorts Involving 306620 Par- 
ticipants. Stroke, 36, 1360-1365. https://doi.org/10.1161/01.STR.0000170710.95689.41

[58] Kengne, A.P., Nakamura, K., Barzi, F., Lam, T.H., Huxley, R., Gu, D., et al. (2009) Smoking, Diabetes and Cardiovascular Diseases in Men in the Asia Pacific Region. Journal of Diabetes, 1, 173-181. https://doi.org/10.1111/j.1753-0407.2009.00028.x

[59] Asia Pacific Cohort Studies Collaboration (2005) Smoking, Quitting, and the Risk of Cardiovascular Disease among Women and Men in the Asia-Pacific Region. International Journal of Epidemiology, 34, 1036-1045. https://doi.org/10.1093/ije/dyi104

[60] Hosey, G.M., Samo, M., Gregg, E.W., Padden, D. and Bibb, S.G. (2014) Socioeconomic and Demographic Predictors of Selected Cardiovascular Risk Factors among Adults Living in Pohnpei, Federated States of Micronesia. BMC Public Health, 14, 895.

https://doi.org/10.1186/1471-2458-14-895

[61] Cho, E.J., Kim, J.H., Sutradhar, S., Yunis, C., Westergaard, M. and Investigators, C.T. (2013) Proactive Multifactorial Intervention Strategy Reduces the Risk of Cardiovascular Disease Estimated with Region-Specific Risk Assessment Models in Pacific Asian Patients Participating in the CRUCIAL Trial. Journal of Korean medical science, 28, 1741-1748. https://doi.org/10.3346/jkms.2013.28.12.1741

[62] Biddle, M., Vincent, G., McCambridge, A., Britton, G., Dewes, O., Elley, C.R., et al. (2011) Randomised Controlled Trial of Informal Team Sports for Cardirespiratory Fitness and Health Benefit in Pacific Adults. Journal of Primary Health Care, 3, 269-277.

[63] Cho, E.J., Kim, J.H., Sutradhar, S., Yunis, C. and Westergaard, M. (2014) Reduction in Cardiovascular Risk Using a Proactive Multifactorial Intervention Is Consistent among Patients Residing in Pacific Asian and Non-Pacific Asian Regions: A CRUCIAL Trial Subanalysis. Vascular Health and Risk Management, 10, 145-156.

https://doi.org/10.2147/VHRM.S54586

\section{Abbreviations}

Cardiovascular disease (CVD), Non-communicable diseases (NCDs), Pacific Island Countries (PIC), Randomized controlled trials (RCTs). 


\section{Appendix 1. Descriptive Studies}

\begin{tabular}{|c|c|c|c|}
\hline $\mathbf{N}$ & Study & Population & Results \\
\hline 1 & $\begin{array}{l}\text { Hyun et al., [8] } \\
\text { Year: } 2013 \\
\text { Type: Cohort study } \\
\text { Country: Asia Pacific }\end{array}$ & $\begin{array}{l}\text { Number: } 386,411 \\
\text { Male: } 386,411 \\
\text { Age: (Mean) } 52 \text { years }\end{array}$ & $\begin{array}{l}\text { 1) Systolic blood pressure } \\
\text { 2) Cholesterol } \\
\text { 3) BMI } \\
\text { 4) Diabetes } \\
\text { 5) Cigarette smoking }\end{array}$ \\
\hline 2 & $\begin{array}{l}\text { Grey et al., [32] } \\
\text { Year: } 2010 \\
\text { Type: Cohort study } \\
\text { Country: New Zealand }\end{array}$ & $\begin{array}{l}\text { Number: } 39,835 \text { (Europeans), } \\
\text { 10,301 Pacific peoples } \\
\text { Age: } 35 \text { to } 74 \text { years }\end{array}$ & $\begin{array}{l}\text { 1) Cigarette Smoking } \\
\text { 2) Diabetes } \\
\text { 3) Diastolic blood pressure } \\
\text { 4) Cholesterol }\end{array}$ \\
\hline 3 & $\begin{array}{l}\text { Huxley et al., [33] } \\
\text { Year: } 2014 \\
\text { Type: Cohort study } \\
\text { Country: Asia Pacific Region }\end{array}$ & $\begin{array}{l}\text { Number: } 543,694 \\
\text { Female: } 36 \% \\
\text { Age: } 18 \text { and over }\end{array}$ & $\begin{array}{l}\text { 1) Systolic Blood pressure } \\
\text { 2) Diabetes } \\
\text { 3) BMI } \\
\text { 4) Cigarette Smoking } \\
\text { 5) Cholesterol }\end{array}$ \\
\hline 4 & $\begin{array}{l}\text { Asia Pacific Cohort Studies } \\
\text { Collaboration, [27] } \\
\text { Year: } 2005 \\
\text { Type: Cohort Study } \\
\text { Country: Asia Pacific }\end{array}$ & $\begin{array}{l}\text { Number: } 331,100 \\
\text { Female: } 41 \% \\
\text { Age: } 39 \text { to } 79 \text { years old }\end{array}$ & $\begin{array}{l}\text { 1) Systolic blood pressure } \\
\text { 2) Cholesterol } \\
\text { 3) Triglycerides } \\
\text { 4) Body Mass Index } \\
\text { 5) Diabetes } \\
\text { 6) Cigarette Smoking }\end{array}$ \\
\hline 5 & $\begin{array}{l}\text { Rana et al., [34] } \\
\text { Year: } 2016 \\
\text { Type: Cohort Study } \\
\text { Country: USA }\end{array}$ & $\begin{array}{l}\text { Number: } 307,591 \text { ( } 22,283 \text { were } \\
\text { black, 52,917 were Asian/Pacific } \\
\text { Islanders, and } 18,745 \text { Hispanic) } \\
\text { Age: between } 40 \text { to } 75 \text { years old }\end{array}$ & 1) Cholesterol \\
\hline 6 & $\begin{array}{l}\text { Lee et al., [35] } \\
\text { Year: } 2009 \\
\text { Type: Cohort study } \\
\text { Country: Asia Pacific Region }\end{array}$ & $\begin{array}{l}\text { Number: } 510,800 \\
\text { Age: } 39 \text { to } 60 \text { years old }\end{array}$ & 1) Sex \\
\hline 7 & $\begin{array}{l}\text { Hosey et al., [36] } \\
\text { Year: } 2014 \\
\text { Type: Cross-sectional Study } \\
\text { Country: Federated States of } \\
\text { Micronesia }\end{array}$ & $\begin{array}{l}\text { Number: } 1638 \\
\text { Male: } 612 \\
\text { Female: } 996 \\
\text { Age: mean age } 39.7 \text { years }\end{array}$ & $\begin{array}{l}\text { 1) Socioeconomic position } \\
\text { 2) Demographic characteristics } \\
\text { (age, gender, and income) }\end{array}$ \\
\hline 8 & $\begin{array}{l}\text { Woodward et al., [11] } \\
\text { Year: } 2007 \\
\text { Type: Cohort Study } \\
\text { Country: Asia Pacific }\end{array}$ & $\begin{array}{l}\text { Number: } 79,649 \\
\text { Female: } 79,649 \\
\text { Age: } 39 \text { - } 79 \text { years }\end{array}$ & 1) Cholesterol \\
\hline 9 & $\begin{array}{l}\text { Association, [37] } \\
\text { Year: } 2004 \\
\text { Type: Cohort Study } \\
\text { Country: Asia Pacific }\end{array}$ & $\begin{array}{l}\text { Number: } 265,464 \\
\text { Age: More than } 20 \text { years old }\end{array}$ & 1) Diabetes \\
\hline
\end{tabular}




\section{Continued}

Asia Pacific Cohort Studies Collaboration, [38]

10 Year: 2003

Type: Cohort Studies

Country: Asia Pacific

Asia Pacific Cohort Studies Collaboration, [39]

11 Year: 2003

Type: Cohort Study

Country: Asia Pacific

Asia Pacific Cohort Studies

Collaboration, [10]

12 Year: 2004

Type: Cohort Study

Country: Asia Pacific Region

Chansavang et al., [40]

13

Year: 2015

Type: Cross Sectional Study

Country: New Zealand

Schaaf et al., [41]

14

Year: 2000

Type: Cross-Sectional Study

Country: New Zealand

Witter et al., [42]

15

Year: 2015

Type: Cross-sectional study Country: Fiji

Asia Pacific Cohort Studies Collaborations, [43]

16

Year: 2006

Type: Cohort Study

Country: Asia Pacific

Nakamura et al., [44]

Year: 2007

Type: Cohort Study

Country: Asia Pacific
Number: 425,325

Age: 60 - 70 years old

Number: 94,147

Female: 94,147

Age: mean age 54

Number: 310,283

Female: $47 \%$

Age: Mean age 47

Number: 18

Male: 4

Female: 14

Age: mean 16.3

Number: 650

Male: Samoans (205), Cook Islands (105), Tongans (55),

Niuean (32)

Female: Samoans (152), Cook

Islands (72), Tongans (16),

Niuean (13)

Age: 40 - 65 years

Number: 834,000

Age: 15 - 64 years

Number: 45,988

Female: $48 \%$

Age: 54 Years

Number: 563,144 (82\% Asians)

Female: $35 \%$

Age: mean age 47 years
1) Age

2) Sex (Gender)

3) Blood Pressure

1) Age

2) Gender

3) Systolic Blood Pressure

4) Diastolic Blood Pressure

5) Mean Arterial Pressure

6) Pulse Pressure

7) Cholesterol

8) Cigarette Smoking

1) Age

2) Gender

3) Body Mass Index

1) Obesity

2) Physical inactivity
1) Diabetes

2) Cholesterol

3) Smoking

4) Physical inactivity

5) BMI

1) Physical inactivity

2) Poor nutrition

3) Excessive alcohol intake

4) Cigarette smoking

5) Obesity

6) Diabetes mellitus

7) High cholesterol

8) High blood pressure

1) Age

2) Sex

3) Ethnicity

4) BMI

1) Cigarette Smoking

2) Increased levels of blood pressure 


\section{Continued}

Asia Pacific Cohort Studies

Collaboration, [45]

18 Year: 2007

Type: Cohort Study

Country: Asia Pacific Region

Asia Pacific Cohort Studies

Collaboration, [46]

19 Year: 2003

Type: Cohort Study

Country: Asia Pacific Region

McDonald-Sundborn et al., [47]

20

Yyear: 2002-2003

Country: New Zealand

Tsukinoki et al., [48]

Year: 2012

21 Type: Cohort Study

Country: Asia Pacific

Asia Pacific Cohort Studies

Collaboration, [49]

22 Year: 2005

Type: Cohort study

Country: Asia Pacific Region

Arima et al., [50]

Year: 2012

23

Type: Cohort Study

Country: Asia Pacific Region

Arima et al., [50]

24

Year: 2008

Type: Cohort Study

Country: Asia Pacific

Dobson et al., [51]

25

Year: 2011

Type: Case Control Study

Country: Fiji

Gu et al., [52]

Year: 2013

26

Type: Cohort Study

Country: New Zealand
Number: 333,533

1) Total Cholesterol

2) Diabetes

Number: 352,033

Female: $42 \%$

1) Cholesterol level

Age: 47 years

Number: 1011 (Samoans: 484,

1) Ethnicity

2) Cigarette Smoking

3) Physical Inactivity

Cook Islands: 116)

Male: 464

Female: 500

Age: 35 - 75 years

4) BMI

5) Blood Pressure

6) Cholesterol

7) Diabetes

Number: 419,488

Age: more than 30 years old

1) Age

2) Elevated Blood Pressure

3) Excess Body Mass Index

4) Smoking

1) Age

Number: 1989

Male: 1063

Female: 926

Age: 20 years and above

Number: 346,570

Male: 204,476.3 (59\%)

Female: 142,093.7 (41\%)

Age: mean 48 years

Number: 380,483 (Adults)

Age: 15 and above

Number: 160

Male: 80

Female: 80

Age: between $5 \& 15$ years

Number: 10,863

Age: 35 years (Men),

45 years (Women)
1) Total Cholesterol

2) Sex

3) Blood Pressure

4) Total Cholesterol

5) BMI

6) Cigarette Smoking

7) Diabetes

1) Smoking

2) Total Cholesterol

1) Genetic Factors that are influence by environmental factors (crowding and poverty)

1) Gender 


\section{Continued}

Martiniuk et al., [30]

27

Year: 2007

Type: Cohort Study

Country: Asia Pacific Region

Martiniuk et al., [30]

28

Year: 2009

Type: Cohort Study

Country: Asia Pacific Region

Huxley et al., [53]

Year: 2011

29

Type: Cohort Study

Country: Asia Pacific Region

Asia Pacific Cohort Studies

Collaboration, [54]

30 Year: 2005

Type: Cohort Study

Country: Asia Pacific Region

Asia Pacific Cohort Studies Collaboration, [54]

31 Year: 2015

Type: Cohort Study

Country: Pacific

Asia Pacific Cohort Studies Collaboration,

32 Year: 2001

Type: Cross Sectional Study Country: Asia Pacific Region

Howard et al., [55]

Year: 2003

33 Type: Cross-Sectional Study Country: United State of America
Number: 600,000

Age: adults

Number: 378,579

Age: 20 years and older

Number: 220,060

Age: 37 - 54 years

Number: 2,547,447

Number: 396

Male: $43.9 \%$

Female: 56.1\%

Age: median age 18 years (Men)

1) Age

2) Sex

3) Ethnicity
1) Low levels of high density

lipoprotein cholesterol
1) Systolic Blood Pressure

2) Serum Cholesterol
Number: 213,515

umber: 3083

Male: None

Female: 1635 (whites), 802 (blacks), 390 (Hispanic), 256 (Asian/Pacific Islanders)

Age: 50 - 79 years
1) Diabetes

2) Physical inactivity

3) Unhealthy Diets

4) Emotional stress
Roy et al., [56]

Year: 2015

34 Type: Cohort Study Country: USA
Number: 8248

Age: 45 - 89 years
1) Insulin resistance syndrome
1) Age

2) Diabetes

3) Hypertension

4) Overweight

5) Obesity

6) Combat service

7) Posttraumatic Stress 


\section{Continued}

Asia Pacific Cohort Studies

Collaboration, [15]

35 Year: 2004

Type: Asia Pacific

Country: Cohort Study

Feigin et al., [57]

36

Year: 2005

Type: Cohort Study

Country: Asia Pacific Region

Kengne et al., [58]

37

Year: 2009

Type: Cohort Study

Country: Asia Pacific Region

Asia Pacific Cohort Studies

Collaboration, [59]

38 Year: 2005

Type: Cohort Study

Country: Asia Pacific

Hosey et al., [60]

Year: 2014

39 Type: Cross-Sectional Study Country: Federated State of Micronesia

Woodward et al., [16]

Year: 2014

40

Type: Cohort Study

Country: Asia Pacific

41 Woodward et al.

Cho et al., [61]

42

Year: 2002

Type: Cohort Study

Country: Asia Pacific
Number: 96,224

Age: 48.4 years

1) Serum triglycerides

Number: 306,620

Age: Mean 48

1) Cigarette Smoking

2) Elevated Blood Pressure

Number: 205,389

Male: 205,389

Age: Men (With diabetes:

5211 years) (without

diabetes: 4811 years)

Number: 463,674 Asian

(33\% female) and 96,664

Australasians (45\% female)

Male: 63\% Asians and 55\%

Australasians

Female: 33\% Asians Female and $45 \%$ Australasians female

Age: Australasians (mean age: 53.2 years) and Asians

(mean age: 46.5 years)

Number: 1639

Male: 642

Female: 996

Age: 25 - 64 years

1) Age

2) Sex

3) Socioeconomic position

Number: 303,036 (71\% Asians)

Male: $32 \%$

Female: $68 \%$

1) Socioeconomic Status

Age: mean: 47 years

Number: 368,307

1) Systolic Blood Pressure

2) Diabetes

Number: 161,214 (58\%

Asians with diabetes)

Male: $50 \%$

1) Age

Female: 50\%

2) Ethnicity

3) Diabetes 


\section{Appendix 2. Intervention Studies}

\begin{tabular}{|c|c|c|c|c|}
\hline $\mathbf{N}$ & Study & Population & Intervention & Results \\
\hline 1 & $\begin{array}{l}\text { Biddle et al., [62] } \\
\text { Year: } 2011 \\
\text { Type: Randomized Controlled Trial } \\
\text { Country: New Zealand }\end{array}$ & $\begin{array}{l}\text { Number: } 20 \\
\text { Male: } 7 \\
\text { Female: } 13 \\
\text { Age: } 34.8 \text { (mean) } \\
\text { Intervention Group members: } 11 \\
\text { Control Group members: } 9\end{array}$ & $\begin{array}{l}\text { Package: Small sided games based exercise } \\
\text { on fitness and health parameters among } \\
\text { pacific adults } \\
\text { How long: } \\
\text { 1) } 45 \text { minutes for intervention participants } \\
\text { three times per week for four weeks. } \\
\text { 2) Control group offered one month gym } \\
\text { membership after the trial }\end{array}$ & $\begin{array}{l}\text { 1) Obesity } \\
\text { 2) Type } 2 \text { diabetes }\end{array}$ \\
\hline 2 & $\begin{array}{l}\text { Cho et al., [63] } \\
\text { Year: } 2014 \\
\text { Type: Randomized Controlled Trial } \\
\text { Country: Asia Pacific, Middle East, } \\
\text { Europe, and Latin America }\end{array}$ & $\begin{array}{l}\text { Number: } 1417 \\
\text { Male: } 284 \text { (Pacific Asians: 63.4\%), } \\
445 \text { (Non-Pacific Asians: 46.9\%) } \\
\text { Female: } 164 \text { (Pacific Asians: 36.6\%), } \\
515 \text { (Non-Pacific Asians: 53.1\%) } \\
\text { Age: } 35 \text { - } 79 \text { years }\end{array}$ & $\begin{array}{l}\text { Package: Proactive Multifactorial } \\
\text { Intervention (PMI) strategy based on } \\
\text { single-pill amlodipine/atorvastatin } \\
\text { (SPAA) and usual care (UC). } \\
\text { How Long: } 12 \text { months }\end{array}$ & 1) Diabetes \\
\hline 3 & $\begin{array}{l}\text { Cho et al., [61] } \\
\text { Year: } 2013 \\
\text { Type: Randomized Controlled Trial } \\
\text { Country: Asia Pacific }\end{array}$ & $\begin{array}{l}\text { Population: } 448 \\
\text { Male: } 284 \\
\text { Female: } 174 \\
\text { Age: } 35 \text { - } 79 \text { years }\end{array}$ & $\begin{array}{l}\text { Package: Proactive Multifactorial Intervention } \\
\text { Strategy based on SPAA and UC } \\
\text { How Long: } 12 \text { months }\end{array}$ & 1) Hypertension \\
\hline
\end{tabular}

Submit or recommend next manuscript to SCIRP and we will provide best service for you:

Accepting pre-submission inquiries through Email, Facebook, LinkedIn, Twitter, etc.

A wide selection of journals (inclusive of 9 subjects, more than 200 journals)

Providing 24-hour high-quality service

User-friendly online submission system

Fair and swift peer-review system

Efficient typesetting and proofreading procedure

Display of the result of downloads and visits, as well as the number of cited articles

Maximum dissemination of your research work

Submit your manuscript at: http://papersubmission.scirp.org/

Or contact wjcs@scirp.org 